\title{
Analysis of landslide potential due to changes of land use/ land cover at the Kuranji watershed, Padang using normalized difference built-up index (NDBI)
}

\author{
Andriani Andriani ${ }^{1 *}$, Geri Despita Putra $^{1}$, Salsabila Ramadhani $^{1}$, Ismael ${ }^{1}$, and Hendri Gusti Putra $^{1}$ \\ ${ }^{1}$ Civil Engineering Departement, Andalas University, Padang, West Sumatera, Indonesia 25163
}

\begin{abstract}
The earthquake and tsunami predictions in the city of Padang have caused very rapid landuse changes, especially in the Kuranji watershed, where people tend to seek locations that are safe from tsunamis and liquefaction. Changes in environmental characteristics such as slope geometry conditions, vegetation density, and changes in land use will affect runoff coefficient and rainwater filtration, triggering a potential for landslides. This study aims to analyze the potential for landslides due to changes in land use in the Kuranji Watershed. The identification of land-use change is carried out using a remote sensing approach, namely the Normalized Difference Built-Up Index (NDBI). Landslide potential is determined based on the relationship between land use and runoff coefficient from 2007 to 2019. The results showed there had been an increase in the built-up area in the Kuranji watershed from 1602.212 ha (2007) to 2897.513 ha (2019). In contrast, the vegetation area has decreased. An increase in the runoff coefficient of 3.9\% from 2007 to 2019 . The final results of this study are thematic geospatial information obtained in the form of the relationship between changes in land use and the potential for landslides that occurred in the Kuranji watershed during the period 2007 to 2019 .
\end{abstract}

\section{Introduction}

Landslides are disasters that often occur in Indonesia. Especially in hilly areas and rivers that have redundant cliff relief. One of the causes of frequent landslides in Indonesia is land-use change. Land-use change is caused by limited areas. West Sumatra is one of the provinces that often experience landslides/slope collapse disasters. The results of monitoring carried out by the Geological Agency, the Center for Volcanology and Geological Disaster Mitigation, in 2011 recorded 21 times the disasters of land movements in West Sumatra that are spread in several districts [1].

This occurs partly due to the factor of high rainfall, very steep slopes $>70(100-150 \%)$, and is an area classified as prone to ground movement (red zone). One area that is vulnerable to slope collapse is Bungus Bay and surrounding areas. The vulnerability of land movements on the coast of Bungus Bay is indicated to be strongly influenced by physical factors such as geology, topography, land use, and rainfall [2]. Slope collapse causes huge economic losses, loss of life and property, environmental damage, and social life. Slope failure is a natural process due to the influence of the earth's gravitational force, unstable slopes, and impermeable rock as a slip plane for the soil or rock on it $[3,4,5]$. The cause of slope collapse can be caused by natural and human factors, namely geological, geomorphological, slope, and climate conditions, including rainfall, humidity, and temperature. Meanwhile, factors caused by humans consist of land use, road network construction, mining activity, and others. Landslides are the mass of rock, soil, or material that makes up the slope (a mixture of soil and rock) moving down the slope. Factors causing natural landslides include earth surface morphology, land use, lithology, geological structure, rainfall, and seismicity [6,7]. Apart from natural factors, landslides are also caused by human activity factors that affect a landscape, such as agricultural activities, slope loading, slope cutting, and mining [8,9]. The main factors causing landslides include slopes, soil texture and type, rainfall, land use, vibrations, the material on cliffs, old landslides, deforestation, and landfill areas. The parameters that cause landslides and based on the weighting model used, and the most considerable influence on the level of landslide vulnerability are the parameters of rainfall and land slope; while rock types and land use have the same weight, then soil type is the parameter with the most influential small one $[10,11]$.

* Corresponding author: andriani@eng.unand.ac.id 
The Kuranji watershed is one of the areas experiencing rapid land-use change. The Kuranji River Basin is included in the green zone area from the danger of tsunamis and liquefaction. According to the BPBD of Padang City, from 2014-2019, five landslides occurred in the Batang Kuranji Watershed (DAS). Landslides arise because they are affected by several conditions, such as morphological conditions, geology, geological structures, hydrogeology, and land use. The use will affect the speed of water flow and the surface flow coefficient; the faster the water flow, and the greater the surface flow coefficient, the faster the erosion process will occur. High erosion will make the area prone to landslides [12]. To interpret land use, it can be done by remote sensing; one of the commonly used indexes is the Normalized Difference Built-up Index (NDBI) and the Normalized Difference Vegetation Index (NDVI) $[13,14,15]$. NDBI is an effective transformation to map built-up areas in cities automatically using Landsat 8 OLI imagery, and using NDBI; it is possible to map urban areas, such as industrial, commercial, and urban residential areas that cannot be separated. Besides, using NDBI can interpret rural areas $[16,17]$. NDBI is an index of built-up area, which is an algorithm to show the density of bare soil [18]. NDBI is very sensitive to developed or open land. This algorithm was chosen because it is the most frequently used transformation to assess the constructed land index. NDBI is an effective transformation to map the limited land area $[19,20]$.

\section{Materials And Methods}

\subsection{Study Area}

The Kuranji watershed is an area that is experiencing rapid changes in land use. Geographically, the Kuranji watershed is located at $100^{\circ} 20^{\prime} 31^{\prime \prime}-100^{\circ} 33^{\prime} 50^{\prime \prime}$ East Longitude and 00 $55^{\prime} 59.88^{\prime \prime}-00^{\circ} 47^{\prime} 24^{\prime \prime}$ South Latitude. While administratively located in Padang City which includes Pauh Subdistrict $\left(120 \mathrm{~km}^{2}\right)$, Kuranji Subdistrict $\left(53.65 \mathrm{~km}^{2}\right)$, Koto Tangah Subdistrict $\left(29.41 \mathrm{~km}^{2}\right)$, Nanggalo Subdistrict $(8.93 \mathrm{~km} 2)$, and North Padang District $\left(3.69 \mathrm{~km}^{2}\right)$. The total area of the Kuranji watershed is approximately $205.6 \mathrm{~km}^{2}$.

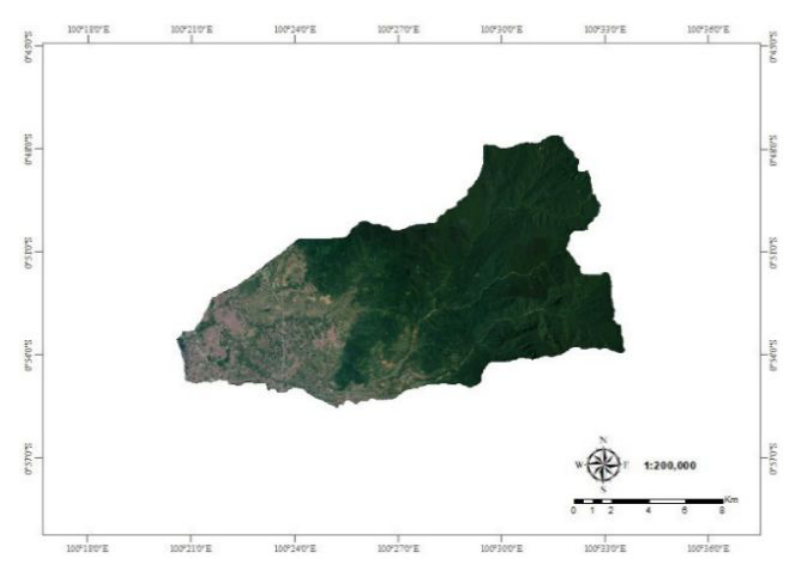

Fig. 1. Location of research at Kuranji Watershed.
The Batang Kuranji watershed flows from the upstream of the row hills with the highest elevation of $\pm 1,605 \mathrm{MSL}$ on the Bukit Tinjau Laut and empties at the Padang beach with the main river length of $\pm 32.41 \mathrm{~km}$ and the total length along with all tributaries of $274.75 \mathrm{~km}$. (Fig. 1).

\subsection{Data Analysis}

This research consists of three stages, land use analysis using NDBI, validating the data by conducting field observations and checking using google earth, and analyzing the potential for landslides based on the value of runoff coefficient on various land use.

The data used to identify land-use change is the Landsat 7 and Landsat 8 imagery data which is downloaded for free from https://earthexplorer.usgs.gov/.

The spatial resolution of the image is $30 \times 30 \mathrm{~m}$. The satellite image data used are Landsat 8 OLI imagery on path/row: $127 / 61$, which was downloaded from the United States Geological Survey (USGS) website. Table 1 shows the types of data used in this study.

Table 1. The data criteria used in this study

\begin{tabular}{|l|l|l|l|}
\hline No. & $\begin{array}{c}\text { Type } \\
\text { Data }\end{array}$ & $\begin{array}{c}\text { Resolution } \\
(\mathbf{m})\end{array}$ & $\begin{array}{c}\text { Date of imagery data } \\
\text { used }\end{array}$ \\
\hline 1. & Landsat 7 & 30 & 19 July 2007 \\
\hline 2. & Landsat 8 & 30 & $\begin{array}{l}\text { 27 April } 2012 \\
\text { 22 July 2017 } \\
\text { 12 July 2019 }\end{array}$ \\
& & \multicolumn{3}{|c|}{} \\
\hline 3 & \multicolumn{3}{|c|}{ The boundary of Kuranji Watershed } \\
\hline
\end{tabular}

Data processing using Quantum Gis 3.14.0. Meanwhile, for data validation interpretation results, use google earth and direct observations in the field.

\subsubsection{Landsat image data processing using the NDBI method}

The data used are in the form of Landsat 7 and Landsat 8 image data. Analysis of Landsat image data was obtained using remote sensing methods, namely by using the NDBI method. The image data that is processed is image data from 2007, 2012, 2015, and 2019. The location of the image data used is the Kuranji watershed. The NDBI formula is as follows:

$$
\mathrm{NDBI}=\frac{\mathrm{SWIR}-\mathrm{NIR}}{\mathrm{SWIR}+\mathrm{NIR}}=\frac{\mathrm{B} 6-\mathrm{B} 5}{\mathrm{~B} 6+\mathrm{B} 5}
$$

Where :

SWIR $=$ Shortwave Infrared or often referred to as band 6

NIR $=$ Near Infrared or often referred to as band 5

\subsubsection{Runoff coefficient analysis}

The runoff coefficient or surface flow coefficient is the ratio between the peak rate of runoff and rain intensity. 
Also referred to as the $\mathrm{C}$ value. The main factors influencing the $\mathrm{C}$ value are the soil infiltration rate, cover cropping, topography and geology, and rain intensity. The following is the runoff coefficient based on land use based on SNI 2415: 2016.

Table 2. Coefficient of runoff $(\mathrm{C})$ per land use/ land cover (LULC).

\begin{tabular}{|c|c|c|}
\hline No. & $\begin{array}{c}\text { Land-Use/Land } \\
\text { Cover }\end{array}$ & $\begin{array}{c}\text { Coefficient of } \\
\text { runoff }\end{array}$ \\
\hline 1. & Mixed Gardens & 0.25 \\
\hline 2. & Commercial & 0.95 \\
\hline 3. & Field & 0.25 \\
\hline 4. & Swap & 0.20 \\
\hline 5. & Rice fields & 0.20 \\
\hline 6. & bush & 0.07 \\
\hline 7. & Industry & 0.90 \\
\hline 8. & pond & 0.20 \\
\hline 9. & mangrove & 0.01 \\
\hline 10. & settlement & 0.40 \\
\hline 11. & bare land & 0.50 \\
\hline 12. & river & 0.00 \\
\hline 13. & education area & 0.70 \\
\hline 14. & garden & 0.30 \\
\hline 15. & tomb & 0.25 \\
\hline 16. & funeral & 0.25 \\
\hline
\end{tabular}

\subsubsection{Validation of data}

The results of the interpretation of land use are then validated using google earth and field observations, it is required that the results of the validation of the interpretation of image data meet $95 \%$ of observations in the field. Furthermore, the area in the Kuranji watershed that has experienced landslides has been checked by using data from the Padang City BPBD. The final result of this study is a thematic map of landslides due to land-use changes in the Kuranji watershed.

\section{Results and Discussion}

\subsection{Interpretation of Land Use/ Land Cover using NDBI at Kuranji watershed}

Analysis of land use/ land cover using NDBI is based on the reflectance value of each band. Furthermore, the guided classification is carried out from the identified map. The land use in this research is divided into 3 types, namely: built-up areas, vegetation areas, and bare-land. The built-up area consists of settlements, office areas, educational areas, and industrial areas. While the vegetation area consists of forests, rice fields, shrubs, rice fields, and dry-land agriculture.

Land use in the Kuranji watershed can be seen in Fig. 2. For vegetation areas are colored green, open areas are colored yellow, and built areas are colored red. From the figure, it can be seen that there is an increase in the builtup area and a decrease in the vegetation area.

\subsubsection{Land Use/Land Cover at 2007}

The area of vegetation is 15631.143 ha or $76.006 \%$ of the total area of the Batang Kuranji watershed. On the land use map, this vegetation class is colored light green; Included in this class are tropical forests, fields, and plantations, as well as areas with dense trees. This vegetated area is spread out in highland areas, including Pauh, Kuranji, and Koto Tangah sub-districts.

In the bare-land class, found an area of 3332.425 hectares, or $16.204 \%$ of the total area of the Kuranji watershed. On the land-use map, the distribution of this class is marked in yellow. Types of land included in this class are empty or dry land, dirt roads, and agricultural areas. This type of class of bare-land is spread across all sub-districts that are included in the Kuranji watershed, namely Pauh, Kuranji, Koto Tangah, Nanggalo, East Padang, and North Padang Districts. In the built-up land class, obtained an area of 1602.212 ha or $7.791 \%$ of the total area of the Kuranji watershed.

On the land-use map, the distribution of this class is marked in red. Types of land included in this class include residential areas, dense buildings, and asphalt roads. The types of classes of built-up land are mostly scattered in coastal areas such as Nanggalo, North Padang, Kuranji, and East Padang Districts.

\subsubsection{Land Use/Land Cover at 2012}

In the area of vegetation class marked with light green on the land use map, it was found that an area of 15768.401 Ha or $76.673 \%$ of the total area was obtained. The types of land included in this class are tropical forests, as well as fields or gardens. The distribution of this class is more focused on the upland and hilly areas, which include Kecamatan Pauh, Kuranji, and Koto Tangah. Bareland in yellow on the land use map has an area of 2954.891 hectares or $14.368 \%$ of the total land area. The types of an area that are included in the bare-land class are vacant land, dirt roads, and agricultural areas.

The distribution of this class is evenly spread across all sub-districts which are included in the Batang Kuranji watershed, namely Pauh, Kuranji, Koto Tangah, Nanggalo, East Padang, and North Padang Districts. Based on the land use map, in 2012, the area of built-up area was 1842.488 hectares or $8.959 \%$ of the total area. On the land-use map, this class is marked in red. Types of the area included in the built-up area class are settlements, solid buildings, asphalt roads, and places that have 
civilian constructions on them. The distribution of this class is more focused on the coastal areas, namely the Nanggalo, North Padang, Kuranji, and East Padang
Districts. The value of Near-Infrared or Band 4 in 2012 is -0.0182003 up to 0.551485 . Meanwhile, the value of Shortwave Infrared or Band 5 is -0.0163216 to 0.45015 .
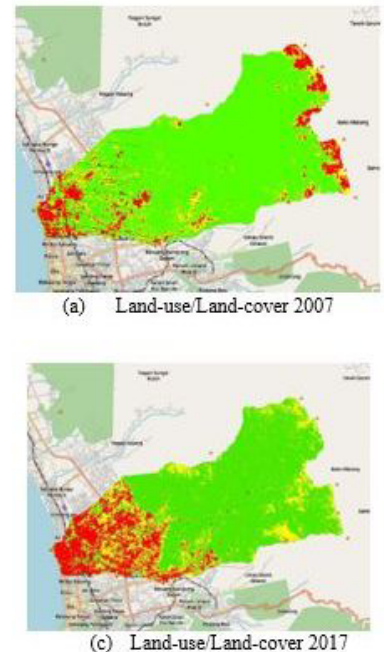

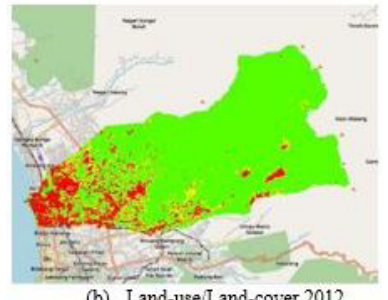

(b) Land-use/Land-cover 2012

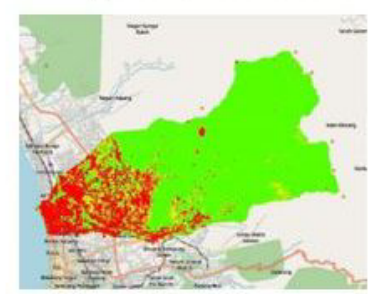

(d) Land-use/Land-cover 2019
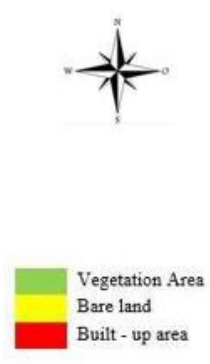

Built - up area

Fig. 2. Interpretation Land-use/ Land-cover using Normalized Difference Built-Up Index (NDBI)

\subsubsection{Land-use/ Land-cover at 2017}

The area of vegetation is 12651,451 hectares or $61.517 \%$ of the total area of the Batang Kuranji watershed. On the land use map, this area class is colored light green. The types of the area included in this class are tropical forests, fields, and plantations as well as areas that have dense trees. This type of vegetation class focuses on the spread of upland areas, which include Pauh, Kuranji, and Koto Tangah Districts. In the bare land class marked in yellow on the land use map, an area of $5315.226 \mathrm{Ha}$ or $25.845 \%$ of the total land area is obtained.

The types of the area that are included in the bare land class are vacant land, dirt roads, and agricultural areas. The distribution of this class is evenly spread across all sub-districts which are included in the Batang Kuranji watershed, namely Pauh, Kuranji, Koto Tangah, Nanggalo, East Padang, and North Padang Districts. Meanwhile, the built-up area using NDBI was obtained for an area of 2599.103 hectares or $12.638 \%$ of the total area of the Batang Kuranji watershed. On the land use map, the distribution of this class is marked in red. Types of land included in this class include residential areas, dense buildings, and asphalt roads. The types of classes of the built-up area are mostly scattered in coastal areas such as Nanggalo, North Padang, Kuranji, and East Padang Districts.

\subsubsection{Land-use/Land-cover at 2019}

The area of vegetation class marked with light green on the land use map, it was found that an area of 14825.048 Ha or $72.086 \%$ of the total area was obtained. The types of the area included in this class are tropical forests, as well as fields or gardens. The distribution of this class is more focused on the upland and hilly areas, which include
Kecamatan Pauh, Kuranji, and Koto Tangah. In the bare land class marked in yellow on the land use map, an area of 2843.329 ha or $13.825 \%$ of the total area is obtained. The types of land that are included in the bare-land class are vacant land, dirt roads, and agricultural areas. The distribution of this class is evenly spread across all subdistricts which are included in the Kuranji watershed, namely Pauh, Kuranji, Koto Tangah, Nanggalo, East Padang, and North Padang Districts.

Based on the land use map, the developed land class has an area of $2897.513 \mathrm{Ha}$ or $14.08 \%$ of the total land area. On the land use map, this class is marked in red. Types of land included in the built-in land class are settlements, solid buildings, asphalt roads, and places that have civilian constructions on them. The distribution of this class is more focused on the coastal areas, namely the Nanggalo, North Padang, Kuranji, and East Padang Districts.

\subsection{Changes in Land-use/ Land-cover at Kuranji Watershed in 2007-2019}

The results of observations show changes in land use in 2007-2019 with using by the NDBI method in the form of Landsat 7 imagery and Landsat 8 imagery, it was obtained 3 class intervals, namely vegetation, bare land, and built-up area. This multitemporal observation resulted in a picture of change in land use/land cover at the Kuranji watershed in 2007, 2012, 2017, and 2019.

Based on Fig. 3, there have been various land use/land cover changes at the Kuranji watershed from 2007-2019. A noticeable change is in the built-up area class, which has increased each year in review. Whereas in the bareland class and vegetation area, the graph fluctuates in each year of review. One of the factors that influence land-use change information is the satellite imagery used in this study. The use of satellite imagery, especially in Landsat 
7 imagery in 2007 and 2012, has been damaged or is often called SLC-Off. This can be seen in the visual appearance of Landsat 7 in 2007 and 2012, which have black lines on their image. As result, the information provided was not optimal when identifying changes in land use in 2007 and 2012 in the Kuranji watershed.

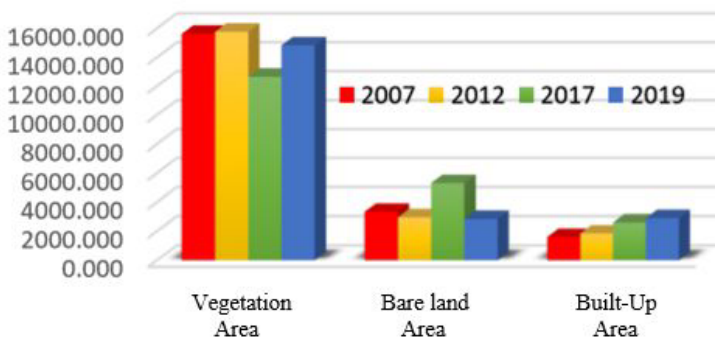

Fig. 3. Changes in Land-use/land-cover at Kuranji Watershed.

\subsection{Relationship between Land-use/Land-cover and the Potential of Landslides at Kuranji Watershed}

From Table 3 and Fig. 3, it can be seen that in 2007 the coefficient of runoff was 0.102 , meaning that $10.2 \%$ of rainwater fell into the runoff. In 2012 there was an increase in runoff coefficient by $0.05 \%$ from 2007 to 0.107 or $10.7 \%$. For 2012 there was another increase of
$3.9 \%$ to 0.146 or $14.6 \%$. Finally, in 2019 there was a slight decrease in the runoff coefficient by $0.5 \%$ to 0.141 or $14.1 \%$. So can see that from 2007-2019 or for 12 years in the Kuranji watershed, the runoff coefficient has increased by $3.9 \%$.

The increase in the runoff coefficient in the Kuranji watershed in the 12 years of review is still relatively safe because the average increase is only $0.325 \%$ per year. Changes in runoff coefficient values are strongly influenced by changes in land use in the Kuranji watershed. It can be seen in Fig. 3, in 2017 and 2019 that there have been significant changes in open-land and vegetation. Open land with a higher $\mathrm{C}$ value decreased in 2019, while vegetation land with a lower $\mathrm{C}$ value increased in 2019.

The resulted in a decrease in the value of the runoff coefficient from 2017 to 2019 by $0.5 \%$. Table 3 and Fig.3, it showed that changes in the coefficient of runoff are strongly influenced by changes in land use within a certain time in the Kuranji watershed. Runoff coefficient values must be continuously monitored every year to know changes in coefficient values of occurs. If the runoff coefficient approaches the value of 1 , further action needs to be taken to change land use in the Kuranji watershed to reduce the potential for landslides. Because it is increasing the value of the coefficient of runoff in an area, the potential for landslides is also increasing because more water becomes runoff; so the potential for surface erosion will also increase

Table 3. Changes in Runoff Coefficient from 2007-2019

\begin{tabular}{|c|c|c|c|c|c|c|c|c|c|}
\hline \multirow[t]{2}{*}{$\begin{array}{l}\text { Type of } \\
\text { LULC }\end{array}$} & \multirow[t]{2}{*}{$\begin{array}{c}\mathrm{C} \\
\text { Value }\end{array}$} & \multicolumn{4}{|c|}{ Area (Ha) } & \multicolumn{4}{|c|}{$(\mathbf{C} \times \mathbf{A}) / \sum \mathbf{A}$} \\
\hline & & 2007 & 2012 & 2017 & 2019 & 2007 & 2012 & 2017 & 2019 \\
\hline $\begin{array}{c}\text { Vegetation } \\
\text { Area }\end{array}$ & 0.03 & 15631.143 & 1576.401 & 12651.451 & 14825.048 & 0.023 & 0.023 & 0.018 & 0.022 \\
\hline $\begin{array}{c}\text { Bare-land } \\
\text { Area }\end{array}$ & 0.15 & 3332.425 & 2954.891 & 5315.226 & 2843.219 & 0.024 & 0.022 & 0.039 & 0.021 \\
\hline $\begin{array}{l}\text { Built-up } \\
\text { area }\end{array}$ & 0.7 & 1602.212 & 1842.488 & 2599.103 & 2897.513 & 0.055 & 0.063 & 0.088 & 0.099 \\
\hline \multicolumn{2}{|c|}{ Total } & 20565.780 & 20565.780 & 20565.780 & 20565.780 & 0.102 & 0.107 & 0.146 & 0.141 \\
\hline
\end{tabular}

\section{Conclusions}

The interpretation of land use/ land cover using NDBI shows that there has been an increase in the built-up area and bare-land in the Kuranji watershed area, while the vegetation area continues to decline. The increase in the built-up area and bare-land has resulted in a higher runoff coefficient, which has resulted in higher potential landslides in the Kuranji watershed.

This research was funded by Andalas University by following the Fundamental Research Scheme, Contract Number: T/22/UN.16.17/PT.01.03/IS-RD/2020 The Fiscal Year 2020.

\section{References}

1. Anonymous. Disaster Info (Actual Monthly Disaster Information), Bulletin National Disaster Management Agency (BNPB), Edition November (2018)

2. L.M., Highland, and P., Bobrowsky, U.S. Geological Survey Circular 1325 (2008)

3. D.G., Bayuaji, A.L., Nugraha, and A., Sukmono, J Geodesi UNDIP, 1 (2016)

4. V.B.S., Chandel, K.K., Brar, and Y., Chauhan, Int Journal of Geomatics and Geosciences, 2 (2011) 
5. V.N., Mishra, P.K., Rai, and K., Mohan, Journal of the Geographical Institute, Jovan Cvijić” SASA (Serbia), 64, 1 (2014)

6. D.M., Cruden, and D.J., Varnes, Transportation Research Board, U.S. National Academy of Sciences, Special Report, 247 (1996)

7. A.B.S.M., Arsjad, and S., Hartini, Majalah Ilmiah Globe, 16, 2 (2004)

8. L.M., Highland, and P., Bobrowsky, United States Geological Survey Circular 1325 (2008)

9. D., Aringoli, B., Gentili, M., Materazzi, and G. Pambianchi, Nova Science Publishers, New York (2010)

10. A., Domenico, B., Marcello, M., Marco, G., Bernardino, and P., Gilberto, Large landslides in seacliff areas of the central Adriatic coast (Italy), in Proceedings of the Second World Landslide Forum 3-7 October 2011, Rome (2011).

11.F.C., Dai, C.F., Lee, and Y.Y., Ngai, Engineering Geology, 64 (2002)
12. G.D., Bathrellos, H.D., Skilodimou, K., Chousianiti, A.M., Youssef, B., Pradhan, Sci. Total Environ., 575 (2017)

13. A., Andriani, E., Ibrahim, D.D.A., Putranto, and Affandy, A.K. , EEC, 6, 2(2018)

14. P., Sinha, N.K., Verma, and E., Ayele, Int Journal of Advanced Remote Sensing and GIS, 5, 8, (2016)

15. E., Li, P., Du, A., Samat, J., Xia, and M., Che, Int Journal of Remote Sensing, 36, 24 (2015)

16. A., Purwanto, Jurnal Edukasi, 13, 1 (2015)

17. S.S., Bhatti, and N.K., Tripathi, GIScience \& Remote Sensing, 51, 4 (2014)

18. X.B., Luo, and W., Li, Journal of Applied Remote Sensing, 8, 9 (2016)

19. H., Xu, Photogrammetric Engineering \& Remote Sensing, 73, 12 ( 2007)

20. Y., Zha, J., Gao, J. and S., Ni, Int. Remote Sensing, 2, $3(2003)$ 